\title{
PENURUNAN BIAYA RANSUM BERBASIS LIMBAH TEBU DENGAN PEMANFAATAN Thitonia diversifolia UNTUK SAPI BALI
}

\author{
Adrizal \\ Fakultas Peternakan Universitas Andalas \\ e-mail: Adrizal_am@yahoo.com
}

\begin{abstract}
ABSTRAK
Penelitian bertujuan untuk meminimumkan biaya ransum sapi bali penggemukan dengan menggunakan limbah tebu sebagai sumber energi dan tumbuhan Thitonia diversifolia sebagai sumber protein. Ransum diformulasikan menggunakan Linear Programming (LP) dengan software QSB+. Data masukan adalah harga, kandungan gizi dan batasan bahan-bahan pakan yang potensial digunakan, serta persyaratan gizi ransum sapi bali. Keluaran dari LP adalah komposisi dan harga ransum komplit. Penelitian dilakukan di sentra produksi gula tebu rakyat di Kenagarian Talang Babungo, Kecamatan Hiliran Gumanti, Kabupaten Solok, Propinsi Sumatera Barat. Bahan-bahan pakan yang potensial disediakan di lokasi penelitian adalah pucuk tebu, ampas tebu (bagasse), limbah cair pengolahan gula tebu, dedak padi, bungkil inti sawit, Thitonia diversifolia, mineral dan garam. Perlakuan penelitian adalah level penggunaan Thitonia diversifolia di dalam ransum yakni $0 \%, 7,5 \%, 15 \%$ dan 22,5\%. Hasil formulasi ransum menunjukkan penurunan jumlah pemakaian bungkil inti sawit dan sebaliknya dapat meningkatkan penggunaan ampas tebu dengan penambahan pemakaian Thitonia diversifolia. Penurunan pemakaian bungkil inti sawit menyebabkan terjadinya penurunan harga ransum. Harga ransum komplit dalam basis bahan kering tanpa menggunakan Thitonia diversifolia adalah Rp. 1481/kg, sedangkan dengan penggunaan sebanyak 7,5\%, 15\% dan 22,5\% menyebabkan harga ransum berturut-turut Rp. 1354/kg, Rp. 1296/kg dan Rp. 1239/kg. Kesimpulan dari penelitian adalah penggunaan Thitonia diversifolia dapat menurunkan biaya ransum sapi bali berbasis limbah tebu.
\end{abstract}

Kata kunci: limbah tebu, Thitonia diversifolia, harga ransum, linear programming, sapi bali

\begin{abstract}
The research is aimed to minimizing the diet costs of bali beef cattle by using sugarcane waste as an energy source and Thitonia diversifolia as a source of protein. Diet formulated using linear programming (LP) with QSB + software. The input data was the price, nutrient content and limitation of the feed stuffs used, as well as nutritional requirements of bali cattle. The output of the LP was composition and price of diet. Research conducted at the center for the production of sugar cane in Kenagarian Talang Babungo, Hiliran Gumanti District, Solok Regency, Sumatera Barat Province. The feed stuffs that are potential is provided on site research was sugar cane top, bagasse, liquid waste processing of sugar cane, rice bran, palm kernel cake, Thitonia diversifolia, minerals and salts. The treatment was the level of use Thitonia diversifolia in rations which is $0 \%, 7.5 \%, 15 \%$ and $22.5 \%$. Diet formulation results showed decreased amounts of usage for palm kernel cake of the using Thitonia diversifolia. The decrease of using palm kernel cake caused minimizing of complete diet cost. The price of the diet (dry matter basis) without Thitonia diversifolia was Rp. 1481/ $\mathrm{kg}$, whereas the use of as much as $7.5 \%, 15 \%$ and $22.5 \%$ caused the price of ration Rp. 1354/kg, Rp. 1296/ $\mathrm{kg}$ to and Rp. 1239/kg respectively. The conclusion was the use of Thitonia diversifolia can minimize the cost of diet for bali beef cattle in the site of research.
\end{abstract}

Keywords: sugar cane waste, Thitonia diversifolia, diet cost, linear programming, Bali cattle.

\section{PENDAHULUAN}

Limbah tebu merupakan bahan pakan yang potensial tersedia di kawasan perkebunan tebu rakyat di Nagari Talang Babungo, Kecamatan Hiliran Gumanti, Kabupaten Solok, Provinsi Sumatera
Barat. Diperkirakan 65\% dari tanaman tebu yang dipanen dibuang menjadi limbah, hanya $35 \%$ yang termanfaatkan menjadi produk gula (Adrizal et al., 2012). Limbah tersebut terdiri dari pucuk tebu (17\%), ampas tebu (46\%) dan limbah cair pengolahan gula tebu (2\%). Luas areal perkebunan tebu rakyat di wilayah ini 415 ha dengan rata-rata produksi 63,69 
ton/ha/tahun, dengan demikian diperkirakan produksi tebu 26.431 ton/tahun, sehingga ketersediaan pucuk tebu, ampas tebu dan limbah cair pembuatan gula berturut-turut 4.493 ton/tahun, 12.158 ton/tahun dan 529 ton/tahun.

Permasalahan dalam pemanfaatan limbah tebu untuk pakan ruminansia adalah masih rendahnya kandungan protein. Kandungan protein kasar pucuk tebu, ampas tebu dan limbah cair pengolahan gula berturut-turut adalah $7,6 \%, 2,15 \%$ dan $12,3 \%$. Berdasarkan kandungan protein tersebut terlihat bahwa untuk memnafaatkannya sebagai ransum penggemukan sapi bali, limbah tersebut perlu disuplementasi dengan bahan pakan lain sebagai sumber protein. Bahan pakan konvensional sebagai sumber protein yang selama ini digunakan adalah bungkil inti sawit dan dedak padi. Bahan pakan sumber protein tersebut harganya relatif mahal, terutama bungkil inti sawit yang didatangkan dari daerah lain. Dalam rangka mengurangi ketergantungan terhadap bungkil inti sawit ini, maka dicari bahan pakan alternatif sebagai sumber protein.

Salah satu bahan pakan alternatif adalah Thitonia diversifolia (TD) yang merupakan tumbuhan liar yang tersebar luas di sekitar wilayah penelitian. Di Indonesia tanaman ini dikenal dengan nama paitan (Firsoni et al., 2010). Selanjutnya dijelaskan bahwa paitan adalah tanaman semak atau perdu famili asteraceae berasal dari Mexico yang tumbuh di daerah tropis lembab dan semi lembab di Amerika Tengah dan Selatan, Asia dan Afrika. Hasil uji laboratorium Balai Pengujian Mutu dan Sertifikasi Pakan (2013) menunjukkan bahwa daun TD mengandung protein kasar sebesar 25,89\%, sedangkanjika daun tidak dipisahkan dengan batangnya hanya mengandung 19,35\%. Kandungan protein bungkil inti sawit seperti yang dilaporkan Widjastuti et al. (2011) hanya 15,14\%, dengan demikian kandungan protein TD lebih tinggi.

Berdasarkan kondisi tersebut maka untuk mendapatkan harga ransum yang lebih murah, tetapi memenuhi syarat kebutuhan gizi sapi Bali penggemukan perlu diformulasikan ransum dengan penggunaan TD tersebut. Formula ransum tersebut dapat diperoleh dengan mempertimbangkan harga dan kandungan gizi, serta batasan penggunaan masingmasing bahan pakan yang potensial disediakan di wilayah penelitian. Data masukan tersebut diolah dengan model linear programming sehingga diperoleh formula ransum dengan harga minimal.

\section{MATERI DAN METODE}

Penelitian diawali dengan mengidentifikasi bahanbahan pakan yang tersedia atau potensial disediakan di wilayah penelitian. Identifikasi meliputi jumlah dan kandungan gizi, serta harga sampai di pabrik pakan mini milik Koperasi Serba Usaha Tabek Talang Babungo, Kecamatan Hiliran Gumanti, Kabupaten Solok, Propinsi Sumatera Barat. Data bahan pakan tersebut dijadikan input bersama dengan data kebutuhan gizi sapi untuk memformulasikan ransum sapi bali penggemukan. Output dari formulasi ransum tersebut adalah formula ransum dengan harga minimum.

Formulasi ransum dilakukan dengan linear programming (LP) menggunakan alat bantu komputer dengan software QSB+. Model matematika LP tersebut (Adrizal et al., 2010) diasjikan sebagai berikut:

Minimumkan $z=\sum_{i=1}^{n} C_{i} X_{i}$

dengan persyaratan/batasan

$\sum_{i=1}^{n} a_{i j} X_{i j} \geq \leq, \leq \operatorname{tau}=b_{j}$

$\sum_{i=1}^{n} a_{i m} X_{i} \geq \leq \leq a t a u=b_{m}$

Dimana:

$\mathrm{z}=$ harga ransum

$\mathrm{n}=$ jumlah macam bahan

$\mathrm{C}_{\mathrm{i}}=$ harga bahan ke- $\mathrm{i}$

$\mathrm{X}_{\mathrm{i}}=$ jumlah penggunaan bahan ke $\mathrm{i}$

$\mathrm{a}_{\mathrm{im}}=$ koefisien teknis bahan ke I batasan ke $\mathrm{j}$

$\mathrm{b}_{\mathrm{j}}=$ batasan $\mathrm{ke} \mathrm{j}$

$\mathrm{m}=$ jumlah batasan

Formulasi ransum dilakukan untuk empat macam perlakuan yakni dengan batasan penggunaan TD yakni $0 \%, 7,5 \%, 15 \%$ dan 22,5\%.

\section{HASIL DAN PEMBAHASAN}

\section{Identifikasi Bahan Pakan}

Data bahan pakan yang tersedia dan potensial disediakan di KSU Tabek Talang Babungo disajikan pada Tabel 1.

Pada Tabel 1 terlihat ada dua macam harga yakni berdasarkan harga segar dan bahan kering. Harga bahan dalam bentuk segar dihitung berdasarkan biaya pembelian dan biaya transportasi sampai di pabrik, serta biaya penanganannya. Harga dalam basis bahan kering diperoleh dengan mengkonversikan harga segar dengan kandungan bahan kering pakan. Data harga dalam basis kering dibutuhkan, karena memformulasikan ransum ruminansia didasarkan atas kandungan bahan kering pakan.

Ada dua macam Thitonia diversifolia yang dianalisis yakni daunnya saja dan utuh semua 
Tabel 1. Data Bahan Pakan di KSU Tabek

\begin{tabular}{|c|c|c|c|c|c|c|c|c|c|}
\hline \multirow{2}{*}{ No. } & \multirow{2}{*}{ Bahan } & \multicolumn{6}{|c|}{ Kandungan gizi (\%) } & \multicolumn{2}{|c|}{ Harga (Rp/kg) } \\
\hline & & BK & PK & TDN & LK & SK & BETN & Segar & BK \\
\hline 1 & Pucuk tebu & 26.4 & 8.49 & 52.5 & 2.9 & 34.5 & 44.69 & 150 & 1,136 \\
\hline 2 & Ampas Tebu & 33.6 & 2.72 & 46.8 & 1.3 & 24.2 & 60.40 & 50 & 149 \\
\hline 3 & LCPGT & 11.1 & 19.67 & 77.6 & 20.0 & 10.4 & 63.98 & 150 & 1,356 \\
\hline 4 & Rumput alam & 24.4 & 8.20 & 56.2 & 1.4 & 31.7 & 44.20 & 400 & 1,639 \\
\hline 5 & Daun Thitonia diversifolia & 15.4 & 25.89 & 67.4 & 5.6 & 14.5 & 37.10 & 500 & 3,249 \\
\hline 6 & Thitonia diversifolia utuh (daun+batang) & 18.4 & 19.35 & 77.2 & 5.8 & 19.4 & 42.06 & 350 & 1,900 \\
\hline 7 & Dedak Padi & 90.6 & 11.46 & 68 & 25.5 & 15.08 & 36.33 & 1,200 & 1,325 \\
\hline 8 & Bungkil inti sawit & 90.3 & 16.80 & 79.0 & 11.9 & 22.6 & 44.60 & 1,850 & 2,049 \\
\hline 9 & Tepung Tulang & 100.0 & & & & & & 5,500 & 5,500 \\
\hline 10 & Garam & 100.0 & & & & & & 2,000 & 2,000 \\
\hline
\end{tabular}

Keterangan: LCPGT = limbah cair pembuatan gula tebu

tanamannnya. Daun Thitonia diversifolia diperoleh dengan memisahkan antara daun dan batang serta ranting-rantingnya, sedangkan yang utuh batang dan rantingnya yang relatif masih lunak tidak dipisahkan. Daun memiliki kandungan gizi yang lebih baik, namun kurang praktis karena setelah dipanen masih dibutuhkan tenaga kerja untuk memisahkan daun dan batang, sehingga menambah biaya. Harga daun dalam basis bahan kering lebih mahal karena disamping tambahan biaya penanganan, juga karena kandungan bahan keringnya lebih rendah.

\section{Formula Ransum}

Hasil formulasi ransum sapi bali disajikan pada Tabel 2. Pada Tabel 2 terlihat bahwa penggunaan ampas tebu meningkat dengan semakin banyaknya pemanfaatan Thitonia diversifolia, sebaliknya penggunaan bungkil inti sawit semakin menurun. Di samping itu dengan penggunaan Thitonia diversifolia pada perlakuan $\mathrm{B}, \mathrm{C}$ dan $\mathrm{D}$ menyebabkan ransum tidak perlu menggunakan rumput alam. Dengan semakin menurunnya penggunaan bungkil inti sawit dan meningkatnya penggunaan ampas tebu menyebabkan penurunan harga ransum.

Tabel 2. Hasil formulasi ransum berbasis limbah tebu dengan empat level penggunaan Thitonia diversifolia (\%)

\begin{tabular}{|c|c|c|c|c|c|}
\hline No & Bahan & A & $B$ & C & D \\
\hline 1 & Daun tebu & 20.0 & 20.0 & 20.0 & 20.0 \\
\hline 2 & Ampas Tebu & 2.6 & 9.7 & 11.1 & 12.4 \\
\hline 3 & Molases & 5.0 & 5.0 & 5.0 & 5.0 \\
\hline 4 & Rumput alam & 9.4 & & & \\
\hline 5 & Thitonia diversifolia utuh & 0.0 & 7.5 & 15.0 & 22.5 \\
\hline 6 & Dedak Padi & 30.0 & 30.0 & 30.0 & 30.0 \\
\hline 7 & Bungkil inti sawit & 30.0 & 24.8 & 15.9 & 7.1 \\
\hline 8 & Tepung Tulang & 2.0 & 2.0 & 2.0 & 2.0 \\
\hline \multirow[t]{3}{*}{9} & Garam & 1.0 & 1.0 & 1.0 & 1.0 \\
\hline & Jumlah & 100 & 100 & 100 & 100 \\
\hline & Harga (Rp/kg BK) & 1.481 & 1.354 & 1.296 & 1.239 \\
\hline
\end{tabular}

\section{SIMPULAN}

Penggunaan Thitonia diversifolia pada ransum komplit berbasis limbah tebu untuk sapi Bali penggemukan dapat meminimumkan biaya ransum.

\section{UCAPAN TERIMA KASIH}

Ucapan terimakasih disampaikan kepada DP2M Dikti yang telah mendanai penelitian melalui proyek Riset Andalan Perguruan Tinggi dan Industri (Rapid) tahun anggaran 2013 dan 2014.

\section{DAFTAR PUSTAKA}

Adrizal, I. Ryanto, Y. Hendri. 2010. Optimasi formulasi ransum sapi potong dengan fuzzy linear programming. Prosiding Seminar Nasional dan Rapat Tahunnan Dekan Bidang Ilmu-Ilmu Pertanian BKPTN Wilayah Barat. Bengkulu 23-25 Mei 2010; 1074-1077.

Adrizal, A. Suprapto, Mirzah. 2012. The potency of sugarcane waste product for supporting beef cattle feed resources at integrated farming center in Solok Regency, West Sumatra. $2^{\text {nd }}$ International Seminar on Animal Industry, Jakarta 5-6 July, 2012; 389-393.

Balai Pengujian Mutu dan Sertifikasi Pakan. 2013. Laporan Hasil Pengujian Sampel Bahan Pakan. Balai Pengujian Mutu dan Sertifikasi pakan No LHP 594/10/2013 Bekasi.

Firsoni, C. Fortuna dan E. Lisanti. 2010. Uji kecernaan invitro dedak padi yang mengandung daun paitan (Thitonia diversifolia (HEMSL.) a gray) dan kelor (Moringga oleifera, Lamk). JITV Vol. 15 No. 3 Th. 2010: 182-187.

Widjastuti, T. Abun, W. Tanwiriah dan I. Y. Asmara. 2007. Pengolahan Bungkil Inti Sawit melalui Fermentasi oleh Jamur Marasmius sp. Guna Menunjang Bahan Pakan Alternatif untuk Ransum Ayam Broiler. Program Hibah Kompetisi A3 Jurusan Produksi Ternak Universitas Padjadjaran Bandung. 